\title{
Does the Quality of Fiscal Institutions Matter for Fiscal Performance? A Panel Data Analysis of European Countries
}

\author{
Mitsi Dimitra ${ }^{1}$ \\ ${ }^{1}$ Department of Economics, University of Piraeus, Piraeus, Greece \\ Correspondence: Mitsi Dimitra, Department of Economics, University of Piraeus, 80, M. Karaoli \& A. Dimitriou \\ St., 18534 Piraeus, Greece. E-mail: mitsidimitra2@gmail.com
}

Received: October 18, 2020

Accepted: December 3, 2020

Online Published: December 10, 2020

doi:10.5539/ijef.v13n1p33

URL: https://doi.org/10.5539/ijef.v13n1p33

\begin{abstract}
The last decade, the number of fiscal frameworks such as national fiscal rules and independent fiscal councils have increased, significantly as a consequence of fiscal indiscipline in many European Countries. In the wake of economic crisis in 2007, fiscal laxity and unsustainable public finances made the European Union to strengthen its fiscal policy in many ways in order to create an economic environment of macroeconomic stability and sustainable growth. This paper investigates the role of fiscal frameworks (fiscal rules and fiscal councils) on fiscal performance as well as the impact of other types of institutions, namely Worldwide Governance Indicators on primary balance. The empirical analysis builds on a reaction function proposed by Bohn (1998) while the estimation method builds on a fixed effect panel data estimation and a dynamic panel data estimation of Arellano-Bover and Blundell-Bond. Our main results provide that political stability, government effectiveness, fiscal rules and fiscal councils play an important role for improving fiscal performance. However, the effect of fiscal institutions on primary balance changes among different types of fiscal rules (debt rules, expenditure rules and budget balanced rules) and independent fiscal councils or fiscal councils that have access to information, respectively.
\end{abstract}

Keywords: fiscal policy, fiscal rules, fiscal councils

\section{Introduction}

Fiscal policy plays an important role for countries as they can use it to improve economic growth (Summers, 2014), to reduce inequalities (Larch \& Turrini, 2010) as well as to improve well-being (Ganell \& Terrala, 2016). However, fiscal policy without fiscal discipline, as a major determinant of sustainable growth, leads to an excessive indebtedness. Therefore, during the decade of 1970 most of the countries and especially industrialized countries created fiscal deficits by issuing public debt. But why some countries create fiscal deficits and others create fiscal surpluses? Which is the role of fiscal discipline in public finances?

The major aspect stands out between disciplined and undisciplined governments. First of all, disciplined governments conduct counter cyclical policies while undisciplined governments conduct procyclical policies. More precisely, by conducting procyclical policies, governments cannot control their expenditures and they intensify fiscal deficits. As a result, it is inevitable that debt will be increased and the governments will adopt strict measures in the near future. Secondly, an undisciplined government is not concerned about prudence which in turn, it promotes a more stable economic environment. Lastly, an undisciplined government does not care about a fair distribution of wealth across generations. But which are the appropriate measures to counter-balance the causes of fiscal indiscipline?

The literature on deficit bias has increased, lately and it analyzes the role of deficit bias on fiscal discipline. However, at this point it is better to report the sources of deficit bias problem before searching for the appropriate solutions.

There are 3 main causes of deficit bias. Time inconsistency is one such cause. There is time inconsistency when policy makers decide to deviate from ex ante policies that were assessed as optimal (Alesina \& Tabellini, 1990). Common-pool problems represent another cause. They arise from special interest groups which pressure governments to spend public revenues for them and not for the common good. As a result, the governments spend public revenues during good times without improving their fiscal position while during economic 
downturn the fiscal position worsens, intensifying excessive deficits and leading to an excessive debt accumulation.

Myopia is another cause of deficit bias. More precisely, policy makers have different preferences than society and as a consequence policy maker pay attention in short-term discretionary actions. Moreover, fiscal adjustments are back-loaded and during good times the public revenues are less because of countercyclical fiscal policies.

Therefore, in the outbreak of the financial crisis and several regional fiscal crises, a huge number of institutional reforms has been implemented as a solution to unsustainable budgetary policies. Since then, fiscal rules and fiscal councils are major determinants of fiscal policy (Figure 1). On the one hand, fiscal rules are neither legislated policy rules nor guidelines. Fiscal rules defined as a permanent constraint (such as a numerical target-debt rule, deficit rule etc.- or a limit for budgetary aggregates) on fiscal policy (Kopits \& Symanski, 1998) and they do not impose constraints on present or future policymakers (Kennedy et al., 2001). In addition, the main objective of fiscal rules is the enhancement of budgetary discipline.

Furthermore, fiscal rules may be seen as a facilitator of more fundamental objectives, such as macroeconomic sustainability, social efficiency, equitable distribution of wealth across generations etc. Nevertheless, the above aims cannot be realized if fiscal policy diverges from social preferences (Milesi-Ferretti, 2004).

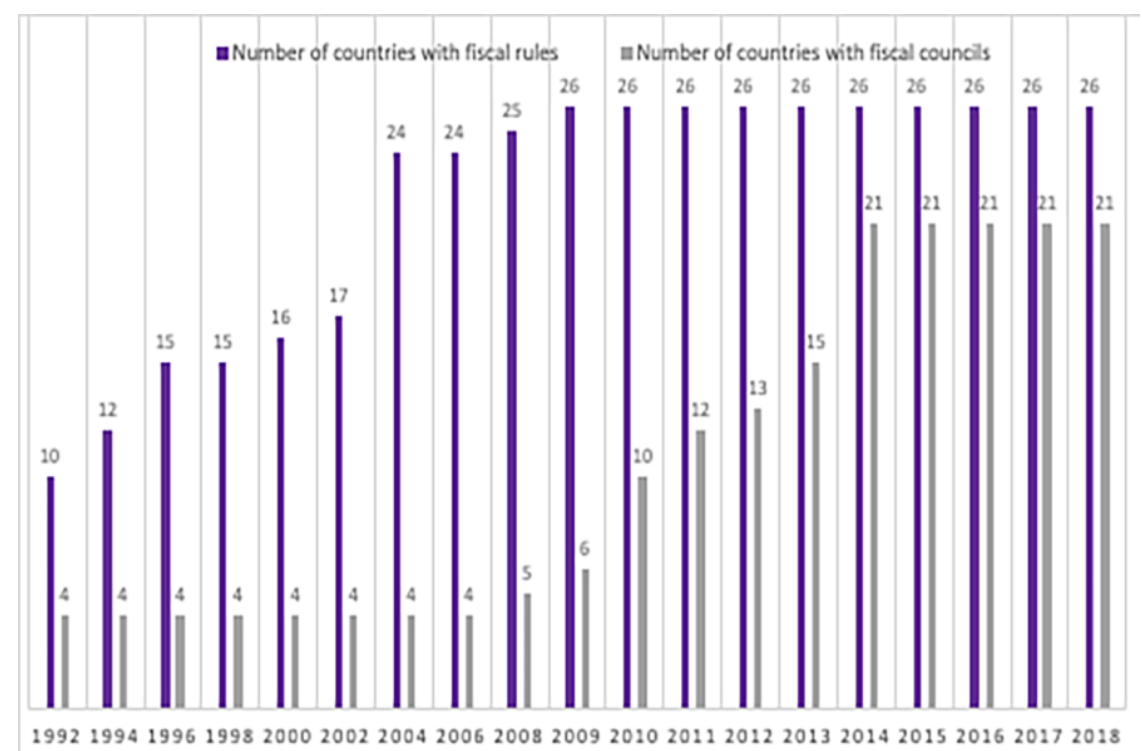

Figure 1. Number of 28-European countries with fiscal rules and fiscal councils (1992-2018)

There are many raisons d'etre of fiscal rules. Firstly, they can help to overcome the problem of deficit bias that comes from the myopia of policy makers and the behavior of rent-seeking. Secondly, they may address the problems that have been paramount in fiscal discipline, notably where political commitment is absent. Nevertheless, fiscal rules have three weaknesses. Firstly, if rules are not constructed carefully, then they can lead to pro-cyclicality (IMF, 2004). Secondly, fiscal rules can be damaging for growth when, for example, public revenues are used to reduce an expenditure cap instead of increase public investment. Thirdly, where political commitment is absent, fiscal rules can undermine transparency through creative accounting and off-budget operation (von Hagen \&Wolff, 2006).

On the other hand, fiscal councils, as non-partisan bodies assist in bypassing this problem. More specifically, they can influence the public debate through independent analyses, policy recommendations, forecasts and or assessments of policy makers decisions. As a result, there is no lack of transparency and policy makers cannot mask the policy failures, by conducting fiscal policies which would lead to excessive deficits and debt accumulation. However, the existence of fiscal councils is not as a substitute for failed rules but they can coexist with fiscal rules and make stronger the enforcement of them (Debrun et al., 2013).

This paper extends the literature regarding the effect of fiscal institutions on fiscal performance in 28 European Countries. First of all, we consider various dimensions of institutions on fiscal performance. For example, we 
use the worldwide governance indicators of Kaufman, the fiscal rule index, dummies for European Monetary Union-expenditure rule-debt rule-budget balance rule-fiscal council-independent fiscal council- access to information fiscal council, as well as a different number of economic determinants of primary balance such as: debt, real growth, trade openness, unemployment and inflation. Second, we use an extensive dataset of 28 European countries over the period of 1996-2018. Furthermore, in a dynamic panel regression model we find that political stability and government effectiveness positively affect primary balance when country has a fiscal rule or a fiscal council. Our results, also indicate that different types of fiscal rules (debt rules, expenditure rules and budget balance rules) have positive effect on fiscal performance as well as independent fiscal councils and fiscal councils that have access to information. Finally, real growth affects positively the primary balance while debt and inflation are not robust and therefore questionable.

The rest of the paper is organized as follows: Section two describes a comprehensive review of the theoretical and empirical literature on fiscal institutions as an explanatory variable of primary balance. The data and methodology are presented in section three; section four presents the empirical results from primary balance panel data estimations. Some useful insights are provided in the last section.

\section{Literature Review}

Ii is well known that the adoption of fiscal rules is positively linked to fiscal performance (IMF, 2009). During the last decade and especially in the outbreak of economic crisis, the adoption of fiscal rules was the "silver bullet" to fiscal indiscipline and macroeconomic forecasting bias. Several empirical researches have reported that the introduction of fiscal rules in many countries lead to higher fiscal balances (ACIR, 1987; Nice, 1991; Eichegreen \& Bayoumi, 1994; Clingermayer \& Wood, 1995; Ayuso-i-Casalo et al., 2007; Debrun et al., 2008; Badinger \& Reuter, 2017; Caselli \& Reynard, 2020).

For instance, Debrun et al. (2008) by using data from 25 European countries show a positive and statistically significant impact of fiscal rules on cyclically adjusted primary balance. However, among different types of fiscal rules, debt and deficit rules are more effective. In a similar dataset and having deficits and long-term debt as dependent variables, Ayuso-i-Casalo et al. (2007) report that the adoption of fiscal rules leads to lower deficits. Badinger and Reuter (2017), by using the new methodology of POSET theory (Badinger \& Reuter, 2015) for 74 countries from 1985 to 2012, confirm that the more stringent fiscal rules are, the higher fiscal balances are. In addition, Bergman et al. (2016), by using a sample of 27 European countries from 1990 to 2012, conclude that the existence of fiscal rules reduces structural primary deficits, while the most effective fiscal rules are budget balanced rules. However, the effectiveness of fiscal rules on fiscal balances is smaller when government effectiveness is high. Moreover, Caselli and Reynard (2020) verify the above results. In particular, by using a sample of 142 countries from 1985 to 2015, they find that well-designed fiscal rules have positive and statistically significant effect on fiscal balances.

The correlation between institutions and fiscal outcomes can be created by many other factors. For example, some countries may adopt fiscal institutions in periods of economic crises of after fiscal consolidation adjustments. At this point, the correlation may be bias because of the problem of endogeneity. Several empirical studies address the problem of endogeneity through many techniques. Most of them use GMM or 2SLS estimations. Debrun and Kumar (2008), for example, use lagged fiscal rule index to assess the impact of fiscal rules on fiscal performance while Badinger and Reuter (2017) use the POSET method. Recent empirical researches fix the endogeneity problem through the methods of treatment effect. For instance, Caselli and Wingender (2018) use the technique of inverse probability weighting. Grembi et al. (2016) use a quasi-experimental design method and Guerguil et al. (2017) the method of propensity score matching.

Economic literature on how fiscal councils help in improving fiscal performance has also increased, lately (EC, 2006; Debrun et al., 2007 Debrun et al., 2017; Beetsma et al., 2019). EC (2006), for example, through an empirical analysis, confirms the strong correlation between fiscal institutions and budgetary outcomes. In particular, it underlines that countries with more well-designed fiscal institutions can achieve sound fiscal policies according to European Union fiscal surveillance objectives. Debrun and Kumar (2007), through a multivariate panel data model for the member states of the European Union over the period of 1990-2004, find that the Stability and Growth Pact and the run up to the EMU affect significantly (negative) the Fiscal Rule Index while Fiscal Council Index is a complementary to the Fiscal Rule Index. Furthermore, Debrun et al. (2012) explore the media impact of fiscal council activity in relation to "real time" fiscal developments. The results demonstrate that fiscal councils' activity and media impact increase in times of budget slippages or relative media impact of fiscal councils is only weakly correlated with subsequent policy changes. The outcomes are consistent with other regression analyses such as pooled OLS or fixed effect. The output gap and public debt 
have negative sign, which means that an increase in the public debt or output gap encourages fiscal activism. IMF (2013), by using an econometric model for 26 countries over the period 1998-2009, find that Fiscal Rule Index, the Fiscal Council legal Independence, Fiscal Council staff number (high level), Fiscal Council high Media Impact, Fiscal Council forecasts provision assessing and Fiscal Rules monitoring appear to have a significant impact on fiscal performance. Finally, Beetsma et al. (2019), by using the 2016 vintage of International Monetary Fund Dataset, report that the existence of a Fiscal Council linked to accurate and realistic forecasts abd greater compliance to fiscal rules.

\section{Methodology and Data}

In this paper we examine the role of fiscal institutions on fiscal performance. All data is annual and the period coverage is from 1996 to 2018 for 28 EU Member States (Austria, Belgium, Bulgaria, Cyprus, Croatia, Czech Republic, Denmark, Estonia, Finland, France, Germany, Greece, Hungary, Ireland. Italy, Latvia, Lithuania, Luxembourg, Malta, Netherlands, Poland, Portugal, Romania, Slovak Republic, Slovenia, Spain, Sweden, United Kingdom.). We use a standard set up often used in the literature (see Debrun et al., 2008; and Hallerberg et al., 2009), which describes a basic reaction function by Bohn (1998).

$$
P B=\alpha+\beta_{1} P B_{l t-1}+\beta_{2} F R+\beta_{3} F C+\gamma V_{i t}+n_{i t}+e_{i t}, \quad t=1,2 \ldots \ldots \ldots . t, i=1,2, \ldots n
$$

where, $\mathrm{PB}$ is the primary balance; FRI is the Fiscal Rule Index; FC is a dummy variable of a Fiscal Council; $\mathrm{V}$ is a set of control variables; ni is the country-specific effect and eit is an unobserved zero mean white noise-type, satisfying the standard assumptions; $a, \beta_{1}, \beta_{2}, \beta_{3}$ and $\gamma$ are unknown coefficients to be estimated.

More precisely, the primary budget balance (PB) is equal to the difference between government's revenue and government expenditures excluding interest payments. We use this variable because it better reflects the fiscal performance of a country. Among the dependent variables, we include the lagged value of the primary balance $\left(P B_{t-1}\right)$, because of autocorrelation. Fiscal Rule index is calculated by taking into account five criteria: (1) the statutory base of the rule, (2) the room for revising objectives, (3) the mechanisms of monitoring compliance and enforcement of the rule, (4) the existence of pre-defined enforcement mechanisms and (5) the media visibility on the rule. Regarding the different types of fiscal rules, we consider balanced budget rules (BBR), debt rules (DR) and expenditure rules (ER) which reflect whether different types of fiscal rules are in place or not (it takes the value "1" for the specific year in which BBR or DR or ER is in place and "0" otherwise, respectively).

Instead of fiscal rules, fiscal councils may be used as another explanatory variable of primary balance. Such institutions have been in place for many years. In 2018, most of the European Countries had been adopted fiscal rules and fiscal councils. However, until now there is no Fiscal Council index to measure the impact of such institutions on fiscal performance. Only, in 2017, European Commission created the Scope Index (SIFI) so as to measure the breadth of fiscal councils' tasks. On this context, we use a dummy variable to measure the existence of a fiscal council. More precisely, a fiscal council dummy (FC) reflects whether a Fiscal Council is in place or not (dummy takes the value " 1 " for the specific year in which Fiscal Council is in place and " 0 " otherwise). Moreover, we use a dummy variable for independent fiscal council (INDFC) (value "1" if there is an independent fiscal council and " 0 " otherwise) as well as a dummy variable for fiscal council which has access to information (ACINFFC) (value " 1 " if there is a fiscal council which has access to information and " 0 " otherwise). In our analysis, we also use the EMU dummy variable which accounts for eurozone membership (dummy takes the value "1" for the specific year if each country has the euro as a currency and " 0 " otherwise).

We also apply several economic variables as independent variables. We include debt as a percentage of GDP (DEBT). Furthermore, we use trade openness as a percentage of GDP (TO). Following Alesina et al. (1999c), Trade Openness is positively associated with larger surpluses, and these effects are more beneficial to open economies. In addition, we include the rate of inflation (INF) and the real GDP growth rate (GROWTH) as determinants of primary balance which represent indicators for the overall economic situation, and positively related to primary budget balances. The unemployment rate (UN) is included since spending for unemployment benefits is higher (hence a negative relationship between UN and PB). Moreover, the Quality of Institutions play an important role in fiscal policy. Countries with good governance and strong institutions tend to attract more investments and to achieve high growth rates. In this context, we also include in our model variables that concern the Government effectiveness (GE), the Control of corruption (COC), the Political Stability (PS), the Rule of Law (ROL), the Regulatory Quality (RQ) and the Voice and Accountability (VAC).

The data was collected from several sources (Table A1). Primary balance, Debt and Unemployment were derived from Eurostat. Data for real growth rate and Trade Openness were derived from the World Bank's Worldwide Development Indicators. Data for Inflation was derived from United Nations Conference on Trade and Development (UNCTAD) database and Fiscal Rule Index from European Commission Database. In addition, 
institutional variables like Government effectiveness, Control of corruption, Political Stability, Rule of Law, Regulatory Quality and Voice and Accountability were derived from the World Bank's Worldwide Governance indicators. Finally, dummies for different types of fiscal rules and fiscal councils are based on the data of International Monetary Fund (IMF) while EMU dummy is based on the European Central Bank (ECB) database.

Our baseline scenario is estimated in a panel setting and we apply various econometric approaches for robustness purposes. The basic methodology is focused on a fixed effects panel model. We start with fixed effects and random effects depending on the relevant statistical tests (Hausman-Test). However, the above estimators do not address the problem of autocorrelation of the residuals and do not deal with the fact that some regressors may be potentially endogenous or predetermined in determining Primary Balance. To account for this potential endogeneity, we also use the Arellano-Bover/Blundell-Bond dynamic panel data model.

\section{Empirical Results}

Table 1 reports the descriptive statistics of the sample indicators during the full sample period (1996-2018) while Table 2 describes the correlation matrix of the Worldwide Governance Indicators (WGI) ranging from -2.5 (weak governance) to +2.5 (strong governance).

Table 1. Descriptive statistics

\begin{tabular}{cccccc}
\hline VARIABLES & OBS & MEAN & SD & MIN & MAX \\
\hline PB & 643 & -2.4993 & 3.4333 & -32.1 & 6.9 \\
DEBT & 639 & 56.5705 & 33.19 & 3.8 & 181.2 \\
GROWTH & 644 & 2.6768 & 3.4857 & -14.8141 & 25.1625 \\
TO & 644 & 111.9208 & 62.7106 & 37.5 & 488.36 \\
UN & 644 & 8.8650 & 4.3399 & 1.8 & 27.47 \\
INF & 644 & 5.2117 & 42.5389 & -4.48 & 1058.37 \\
EMU & 644 & 0.4440 & 0.4972 & 0 & 1 \\
GE & 644 & 1.1386 & 0.6294 & -0.57 & 2.35 \\
PS & 644 & 0.8149 & 0.4338 & -0.47 & 1.76 \\
RQ & 644 & 1.1604 & 0.4614 & --0.18 & 2.1 \\
ROL & 644 & 1.1107 & 0.6271 & -0.63 & 2.1 \\
COC & 644 & 1.0415 & 0.8033 & -0.62 & 2.47 \\
VAC & 644 & 1.1202 & 0.3468 & -0.29 & 1.8 \\
FRI & 644 & 0.2056 & 1.0064 & -0.97 & 3.25 \\
ER & 644 & 0.4891 & 0.5002 & 0 & 1 \\
DR & 644 & 0.8524 & 0.3548 & 0 & 1 \\
BBR & 644 & 0.8307 & 0.3752 & 0 & 1 \\
FC & 644 & 0.3214 & 0.4673 & 0 & 1 \\
INDFC & 644 & 0.2795 & 0.4491 & 0 & 1 \\
ACINFFC & 644 & 0.2391 & 0.4268 & 0 & 1 \\
& & & & \\
\hline
\end{tabular}

Table 2. Correlation of the worldwide governance indicators from1996 to 2018

\begin{tabular}{ccccccc}
\hline VARIABLES & PS & GE & VAC & ROL & RQ & COC \\
\hline PS & 1.0000 & & & & & \\
GE & 0.5872 & 1.0000 & & & & \\
VAC & 0.6144 & 0.8952 & 1.0000 & & & \\
ROL & 0.6043 & 0.9412 & 0.9322 & 1.0000 & & \\
RQ & 0.5514 & 0.8546 & 0.8576 & 0.8833 & 1.0000 & 1.0000 \\
COC & 0.5698 & 0.9455 & 0.9133 & 0.9502 & 0.8644 & \\
\hline
\end{tabular}

Table 3 describes the fixed effects panel estimation for 28 European Countries according to 8 different model specifications. The empirical outcome in the first column analyses the estimated coefficients for the basic model of equation (1) while the other 7 columns indicate an alternative version of the equation (1) so as to examine for additional explanatory variables of primary balance. The basic equation of the other columns (from 2 to 8 ) can be found in the Data and Methodology section.

The empirical results in column 1 of Table 3 indicate a positive and statistically significant relationship between 
primary balance and one-lagged primary balance, debt, growth, trade openness and inflation, respectively. As a result, it is obvious that these results verify our initial hypotheses and are consistent with the relevant literature, as well. At the same time, according to the results of columns 2 to 8 in Table 3, European Monetary Union does not have a statistically significant impact on primary balance. However, Fiscal Rule Index, political stability, government effectiveness and Fiscal Council display significant coefficients of the expected sign.

By using the other panel data estimation method, namely Arellano-Bover/Blundell-Bond dynamic panel estimations (Table 4), we verify the dynamic correlation between primary balance at time $t$ and primary balance at time $\mathrm{t}$ minus 1 . In other words, we confirm the positive and statistically significant dynamic correlation between primary balance and one-lagged primary balance. In addition, growth, fiscal rule index, political stability, government effectiveness and fiscal council report statistically significant relationship of the expected sign with the dependent variable while the rest of the variables have no statistically significant relationship with the primary balance.Surprisingly, debt, trade openness and inflation do not provide any statistically significant correlation with the primary balance confirming the existence of heterogeneity even if we use fixed effects.

Next, we examine how different types of fiscal rules (budget balanced rule, debt rule and expenditure rule) and fiscal councils (independent fiscal councils and fiscal councils that have access to information) impact on primary balance. According to Table 5 and Table 6, all types of fiscal rules and fiscal councils have significant effects on primary balance.

To complement the empirical analysis, we examine the impact of combinations among fiscal rules as well as between fiscal councils (Table 7 and Table 8). In particular, we find that all the combinations among fiscal rules as well as between fiscal councils are statistically significant.

Table 3. Fixed effects panel data estimations for 28 European countries from 1996 to 2018 (annual data)

\begin{tabular}{|c|c|c|c|c|c|c|c|c|}
\hline Variables & Basic Model (1) & (2) & (3) & (4) & (5) & (6) & (7) & (8) \\
\hline L.PB & $\begin{array}{c}0.616 * * * \\
(0.033)\end{array}$ & $\begin{array}{c}0.617 * * * \\
(0.034)\end{array}$ & $\begin{array}{c}0.607 * * * \\
(0.035)\end{array}$ & $\begin{array}{c}0.602 * * * \\
(0.037)\end{array}$ & $\begin{array}{c}0.603 * * * \\
(0.037)\end{array}$ & $\begin{array}{c}0.603 * * * \\
(0.036)\end{array}$ & $\begin{array}{c}0.601 * * * \\
(0.037)\end{array}$ & $\begin{array}{c}0.601 * * * \\
(0.037)\end{array}$ \\
\hline DEBT & $\begin{array}{c}0.020 * * * \\
(0.006)\end{array}$ & $\begin{array}{c}0.021 * * * \\
(0.006)\end{array}$ & $\begin{array}{c}0.017 * * \\
(0.007)\end{array}$ & $\begin{array}{c}0.016^{* *} \\
(0.007)\end{array}$ & $\begin{array}{c}0.016 * * \\
(0.007)\end{array}$ & $\begin{array}{c}0.011 \\
(0.007)\end{array}$ & $\begin{array}{c}0.009 \\
(0.008)\end{array}$ & $\begin{array}{c}0.009 \\
(0.008)\end{array}$ \\
\hline GROWTH & $\begin{array}{c}0.300 * * * \\
(0.028)\end{array}$ & $\begin{array}{c}0.298 * * * \\
(0.029)\end{array}$ & $\begin{array}{c}0.299 * * * \\
(0.028)\end{array}$ & $\begin{array}{c}0.291 * * * \\
(0.027)\end{array}$ & $\begin{array}{c}0.299 * * * \\
(0.028)\end{array}$ & $\begin{array}{c}0.298 * * * \\
(0.028)\end{array}$ & $\begin{array}{c}0.299 * * * \\
(0.027)\end{array}$ & $\begin{array}{c}0.299 * * * \\
(0.027)\end{array}$ \\
\hline TO & $\begin{array}{c}0.011^{* *} \\
(0.005)\end{array}$ & $\begin{array}{l}0.011 * * \\
(0.005)\end{array}$ & $\begin{array}{c}0.008 \\
(0.005)\end{array}$ & $\begin{array}{c}0.009 \\
(0.005)\end{array}$ & $\begin{array}{c}0.008 \\
(0.005)\end{array}$ & $\begin{array}{c}0.007 \\
(0.006)\end{array}$ & $\begin{array}{c}0.008 \\
(0.006)\end{array}$ & $\begin{array}{c}0.008 \\
(0.006)\end{array}$ \\
\hline UN & $\begin{array}{l}-0.050 \\
(0.054)\end{array}$ & $\begin{array}{l}-0.051 \\
(0.053)\end{array}$ & $\begin{array}{l}-0.044 \\
(0.053)\end{array}$ & $\begin{array}{l}-0.035 \\
(0.052)\end{array}$ & $\begin{array}{l}-0.029 \\
(0.049)\end{array}$ & $\begin{array}{l}-0.038 \\
(0.052)\end{array}$ & $\begin{array}{l}-0.021 \\
(0.048)\end{array}$ & $\begin{array}{l}-0.021 \\
(0.048)\end{array}$ \\
\hline INF & $\begin{array}{c}0.015^{* * *} \\
(0.006)\end{array}$ & $\begin{array}{c}0.015^{* *} \\
(0.006)\end{array}$ & $\begin{array}{c}0.017 * * * \\
(0.006)\end{array}$ & $\begin{array}{c}0.017 \text { *** } \\
(0.006)\end{array}$ & $\begin{array}{c}0.020^{* * * *} \\
(0.006)\end{array}$ & $\begin{array}{c}0.019 * * * \\
(0.006)\end{array}$ & $\begin{array}{c}0.022 * * * \\
(0.007)\end{array}$ & $\begin{array}{c}0.022^{* * * *} \\
(0.007)\end{array}$ \\
\hline EMU & & $\begin{array}{l}-0.078 \\
(0.166)\end{array}$ & & & & & & \\
\hline FRI & & & $\begin{array}{l}0.174 * \\
(0.098)\end{array}$ & $\begin{array}{c}0.228^{* *} \\
(0.109)\end{array}$ & $\begin{array}{l}0.206^{*} \\
(0.104)\end{array}$ & $\begin{array}{c}0.068 \\
(0.112)\end{array}$ & & \\
\hline PS & & & & $\begin{array}{l}0.737 * \\
(0.398)\end{array}$ & & & & \\
\hline GE & & & & & $\begin{array}{l}0.886^{*} \\
(0.501)\end{array}$ & & $\begin{array}{c}1.036^{* * *} \\
(0.500)\end{array}$ & $\begin{array}{l}1.036^{* *} \\
(0.500)\end{array}$ \\
\hline $\mathrm{FC}$ & & & & & & $\begin{array}{c}0.583 \\
(0.411)\end{array}$ & $\begin{array}{l}0.764 * \\
(0.397)\end{array}$ & $\begin{array}{l}0.764 * \\
(0.397)\end{array}$ \\
\hline Constant & $\begin{array}{c}-3.627 * * * \\
(0.858)\end{array}$ & $\begin{array}{c}-3.631 * * * \\
(0.864)\end{array}$ & $\begin{array}{c}-3.259 * * * \\
(0.911)\end{array}$ & $\begin{array}{c}-3.985^{* * *} \\
(0.797)\end{array}$ & $\begin{array}{c}-4.375^{* * *} \\
(0.630)\end{array}$ & $\begin{array}{c}-3.034 * * * \\
(0.994)\end{array}$ & $\begin{array}{c}-4.423 * * * \\
(0.676)\end{array}$ & $\begin{array}{c}-4.423 * * * \\
(0.676)\end{array}$ \\
\hline Obseravtions & 612 & 612 & 612 & 612 & 612 & 612 & 612 & 612 \\
\hline R-squared & 0.560 & 0.560 & 0.561 & 0.564 & 0.564 & 0.564 & 0.568 & 0.568 \\
\hline Number of id & 28 & 28 & 28 & 28 & 28 & 28 & 28 & 28 \\
\hline
\end{tabular}

Note. The table reports the estimates of the coefficients and their standard deviation for the period from 1996 to 2018. The basic equation of the other columns (from 2 to 8 ) can be found in the Data and Methodology section. ****** Denote significance level of $10 \%, 5 \%$ and $1 \%$, respectively. 
Table 4. Arellano-Bover/Blundell-Bond dynamic panel data estimations for 28 European countries from 1996 to 2018 (annual data)

\begin{tabular}{|c|c|c|c|c|c|c|c|c|}
\hline Variables & Basic Model (1) & (2) & (3) & (4) & (5) & (6) & (7) & (8) \\
\hline L.PB & $\begin{array}{c}0.659 * * * \\
(0.031)\end{array}$ & $\begin{array}{c}0.655^{* * * *} \\
(0.031)\end{array}$ & $\begin{array}{c}0.588 * * * \\
(0.037)\end{array}$ & $\begin{array}{c}0.598 * * * \\
(0.037)\end{array}$ & $\begin{array}{c}0.617 * * * \\
(0.037)\end{array}$ & $\begin{array}{c}0.592 * * * \\
(0.037)\end{array}$ & $\begin{array}{c}0.643 * * * \\
(0.033)\end{array}$ & $\begin{array}{c}0.656 * * * \\
(0.033)\end{array}$ \\
\hline DEBT & $\begin{array}{c}0.005 \\
(0.003)\end{array}$ & $\begin{array}{c}0.003 \\
(0.004)\end{array}$ & $\begin{array}{c}0.002 \\
(0.003)\end{array}$ & $\begin{array}{c}0.003 \\
(0.003)\end{array}$ & $\begin{array}{c}0.002 \\
(0.003)\end{array}$ & $\begin{array}{l}-0.001 \\
(0.003)\end{array}$ & $\begin{array}{l}-0.002 \\
(0.004)\end{array}$ & $\begin{array}{l}-0.001 \\
(0.004)\end{array}$ \\
\hline GROWTH & $\begin{array}{c}0.301 * * * \\
(0.030)\end{array}$ & $\begin{array}{c}0.305 * * * \\
(0.031)\end{array}$ & $\begin{array}{c}0.308 * * * \\
(0.032)\end{array}$ & $\begin{array}{c}0.302 * * * \\
(0.030)\end{array}$ & $\begin{array}{c}0.307 * * * \\
(0.031)\end{array}$ & $\begin{array}{c}0.307 * * * \\
(0.031)\end{array}$ & $\begin{array}{c}0.299 * * * \\
(0.029)\end{array}$ & $\begin{array}{c}0.303 * * * \\
(0.030)\end{array}$ \\
\hline TO & $\begin{array}{c}0.001 \\
(0.003)\end{array}$ & $\begin{array}{c}0.001 \\
(0.003)\end{array}$ & $\begin{array}{c}0.001 \\
(0.003)\end{array}$ & $\begin{array}{l}-0.000 \\
(0.003)\end{array}$ & $\begin{array}{c}0.001 \\
(0.002)\end{array}$ & $\begin{array}{c}0.000 \\
(0.003)\end{array}$ & $\begin{array}{l}-0.001 \\
(0.003)\end{array}$ & $\begin{array}{c}0.000 \\
(0.002)\end{array}$ \\
\hline UN & $\begin{array}{l}-0.039 \\
(0.035)\end{array}$ & $\begin{array}{l}-0.036 \\
(0.035)\end{array}$ & $\begin{array}{l}-0.060 \\
(0.036)\end{array}$ & $\begin{array}{l}-0.031 \\
(0.039)\end{array}$ & $\begin{array}{l}-0.015 \\
(0.039)\end{array}$ & $\begin{array}{l}-0.049 \\
(0.036)\end{array}$ & $\begin{array}{l}-0.004 \\
(0.039)\end{array}$ & $\begin{array}{c}0.007 \\
(0.038)\end{array}$ \\
\hline INF & $\begin{array}{l}-0.004 \\
(0.013)\end{array}$ & $\begin{array}{l}-0.003 \\
(0.012)\end{array}$ & $\begin{array}{c}0.005 \\
(0.008)\end{array}$ & $\begin{array}{c}0.010 \\
(0.007)\end{array}$ & $\begin{array}{c}0.020 * * * \\
(0.006)\end{array}$ & $\begin{array}{c}0.004 \\
(0.008)\end{array}$ & $\begin{array}{c}0.003 \\
(0.010)\end{array}$ & $\begin{array}{c}0.013 \\
(0.009)\end{array}$ \\
\hline EMU & & $\begin{array}{c}0.245 \\
(0.273)\end{array}$ & & & & & & \\
\hline FRI & & & $\begin{array}{c}0.514 * * * \\
(0.087)\end{array}$ & $\begin{array}{c}0.550 * * * \\
(0.086)\end{array}$ & $\begin{array}{c}0.457 * * * \\
(0.081)\end{array}$ & $\begin{array}{c}0.380 * * * \\
(0.093)\end{array}$ & & \\
\hline PS & & & & $\begin{array}{c}0.749 * * \\
(0.287)\end{array}$ & & & $\begin{array}{l}0.620^{*} \\
(0.340)\end{array}$ & \\
\hline GE & & & & & $\begin{array}{c}0.618 * * * \\
(0.187)\end{array}$ & & & $\begin{array}{c}0.539 * * \\
(0.214)\end{array}$ \\
\hline FC & & & & & & $\begin{array}{c}0.554 \\
(0.326)\end{array}$ & $\begin{array}{c}1.045^{* * * *} \\
(0.261)\end{array}$ & $\begin{array}{c}0.856^{* * * *} \\
(0.266)\end{array}$ \\
\hline Constant & $\begin{array}{c}-1.644 * * * \\
(0.573)\end{array}$ & $\begin{array}{c}-1.648 * * * \\
(0.574)\end{array}$ & $\begin{array}{c}-1.624 * * \\
(0.591)\end{array}$ & $\begin{array}{c}-2.316^{* * * *} \\
(0.577)\end{array}$ & $\begin{array}{c}-2.647 * * * \\
(0.598)\end{array}$ & $\begin{array}{c}-1.609 * * * \\
(0.563)\end{array}$ & $\begin{array}{c}-2.181 * * * \\
(0.602)\end{array}$ & $\begin{array}{c}-2.509 * * * \\
(0.622)\end{array}$ \\
\hline Sargan Test & 84.07 & 83.78 & 72.33 & 74.81 & 74.00 & 71.69 & 77.62 & 76.85 \\
\hline $\operatorname{ar}(2)$ & 0.219 & 0.222 & 0.301 & 0.280 & 0.270 & 0.281 & 0.211 & 0.213 \\
\hline Observations & 612 & 612 & 612 & 612 & 612 & 612 & 612 & 612 \\
\hline Number of id & 28 & 28 & 28 & 28 & 28 & 28 & 28 & 28 \\
\hline
\end{tabular}

Note. The table reports the estimates of the coefficients and their standard deviation for the period from 1996 to 2018. The basic equation of the other columns (from 2 to 8 ) can be found in the Data and Methodology section. ****** Denote significance level of 10\%, 5\% and 1\%, respectively.

Table 5. Fixed effects panel data estimations for 28 European countries from1996 to 2018 (annual data)

\begin{tabular}{|c|c|c|c|c|c|c|c|}
\hline Variables & Basic Model (1) & (2) & (3) & (4) & (5) & (6) & (7) \\
\hline L.PB & $\begin{array}{c}0.607 * * * \\
(0.035)\end{array}$ & $\begin{array}{c}0.604 * * * \\
(0.034)\end{array}$ & $\begin{array}{c}0.612 * * * \\
(0.033)\end{array}$ & $\begin{array}{c}0.613 * * * \\
(0.033)\end{array}$ & $\begin{array}{c}0.606 * * * \\
(0.036)\end{array}$ & $\begin{array}{c}0.605^{* * * *} \\
(0.036)\end{array}$ & $\begin{array}{c}0.603 * * * \\
(0.036)\end{array}$ \\
\hline DEBT & $\begin{array}{c}0.017 * * \\
(0.007)\end{array}$ & $\begin{array}{c}0.010 \\
(0.007)\end{array}$ & $\begin{array}{c}0.019 * * * \\
(0.006)\end{array}$ & $\begin{array}{c}0.018 * * * \\
(0.006)\end{array}$ & $\begin{array}{c}0.012 \\
(0.007)\end{array}$ & $\begin{array}{l}0.012^{*} \\
(0.007)\end{array}$ & $\begin{array}{c}0.009 \\
(0.007)\end{array}$ \\
\hline GROWTH & $\begin{array}{c}0.299 * * * \\
(0.028)\end{array}$ & $\begin{array}{c}0.306^{* * * *} \\
(0.028)\end{array}$ & $\begin{array}{c}0.310 * * * \\
(0.028)\end{array}$ & $\begin{array}{c}0.308^{* * * *} \\
(0.029)\end{array}$ & $\begin{array}{c}0.299 * * * \\
(0.028)\end{array}$ & $\begin{array}{c}0.299 * * * \\
(0.028)\end{array}$ & $\begin{array}{c}0.297 * * * \\
(0.028)\end{array}$ \\
\hline TO & $\begin{array}{c}0.008 \\
(0.005)\end{array}$ & $\begin{array}{c}0.006 \\
(0.005)\end{array}$ & $\begin{array}{c}0.007 \\
(0.005)\end{array}$ & $\begin{array}{c}0.006 \\
(0.005)\end{array}$ & $\begin{array}{c}0.008 \\
(0.006)\end{array}$ & $\begin{array}{c}0.007 \\
(0.006)\end{array}$ & $\begin{array}{c}0.007 \\
(0.006)\end{array}$ \\
\hline UN & $\begin{array}{l}-0.044 \\
(0.053)\end{array}$ & $\begin{array}{l}-0.033 \\
(0.055)\end{array}$ & $\begin{array}{l}-0.039 \\
(0.054)\end{array}$ & $\begin{array}{l}-0.034 \\
(0.053)\end{array}$ & $\begin{array}{l}-0.040 \\
(0.052)\end{array}$ & $\begin{array}{l}-0.045 \\
(0.053)\end{array}$ & $\begin{array}{l}-0.037 \\
(0.051)\end{array}$ \\
\hline INF & $\begin{array}{c}0.017 * * * \\
(0.006)\end{array}$ & $\begin{array}{c}0.019 * * * \\
(0.006)\end{array}$ & $\begin{array}{c}0.022 * * * \\
(0.007)\end{array}$ & $\begin{array}{c}0.022 * * * \\
(0.007)\end{array}$ & $\begin{array}{c}0.018^{* *} \\
(0.006)\end{array}$ & $\begin{array}{c}0.018^{* *} \\
(0.007)\end{array}$ & $\begin{array}{c}0.018^{* * * *} \\
(0.007)\end{array}$ \\
\hline FRI & $\begin{array}{l}0.174^{*} \\
(0.098)\end{array}$ & & & & & & \\
\hline ER & & $\begin{array}{c}0.665^{* *} \\
(0.271)\end{array}$ & & & & & \\
\hline DR & & & $\begin{array}{c}0.700 * * \\
(0.302)\end{array}$ & & & & \\
\hline
\end{tabular}




\begin{tabular}{|c|c|c|c|c|c|c|c|}
\hline BBR & & & & $\begin{array}{c}0.673 * * \\
(0.313)\end{array}$ & & & \\
\hline FC & & & & & $\begin{array}{l}0.646^{*} \\
(0.368)\end{array}$ & & \\
\hline INDFC & & & & & & $\begin{array}{l}0.666^{*} \\
(0.380)\end{array}$ & \\
\hline ACINFFC & & & & & & & $\begin{array}{l}0.753 * \\
(0.403)\end{array}$ \\
\hline Constant & $\begin{array}{c}-3.259 * * * \\
(0.911)\end{array}$ & $\begin{array}{c}-3.122 * * * \\
(0.888)\end{array}$ & $\begin{array}{c}-3.932 * * * \\
(0.783)\end{array}$ & $\begin{array}{c}-3.806^{* * *} \\
(0.787)\end{array}$ & $\begin{array}{c}-3.130 * * * \\
(1.013)\end{array}$ & $\begin{array}{c}-3.054 * * * \\
(1.047)\end{array}$ & $\begin{array}{c}-2.948^{* *} * \\
(1.069)\end{array}$ \\
\hline Observations & 612 & 612 & 612 & 612 & 612 & 612 & 612 \\
\hline R-squared & 0.561 & 0.565 & 0.564 & 0.563 & 0.564 & 0.564 & 0.565 \\
\hline Number of id & 28 & 28 & 28 & 28 & 28 & 28 & 28 \\
\hline
\end{tabular}

Note. The table reports the estimates of the coefficients and their standard deviation for the period from 1996 to 2018 . The basic equation of the other columns (from 2 to 8 ) can be found in the Data and Methodology section. ****** Denote significance level of $10 \%, 5 \%$ and $1 \%$, respectively.

Table 6. Arellano-Bover/Blundell-Bond dynamic panel data estimations for 28 European countries from 1996 to 2018 (annual data)

\begin{tabular}{|c|c|c|c|c|c|c|c|}
\hline Variables & Basic model (1) & (2) & (3) & (4) & (5) & (6) & (7) \\
\hline L.PB & $\begin{array}{c}0.588 * * * \\
(0.037)\end{array}$ & $\begin{array}{c}0.595 * * * \\
(0.035)\end{array}$ & $\begin{array}{c}0.640 * * * \\
(0.033)\end{array}$ & $\begin{array}{c}0.636^{* * *} \\
(0.033)\end{array}$ & $\begin{array}{c}0.627 * * * \\
(0.031)\end{array}$ & $\begin{array}{c}0.624 * * * \\
(0.032)\end{array}$ & $\begin{array}{c}0.634 * * * \\
(0.031)\end{array}$ \\
\hline DEBT & $\begin{array}{c}0.002 \\
(0.003)\end{array}$ & $\begin{array}{l}-0.001 \\
(0.004)\end{array}$ & $\begin{array}{c}0.002 \\
(0.003)\end{array}$ & $\begin{array}{c}0.001 \\
(0.003)\end{array}$ & $\begin{array}{l}-0.002 \\
(0.004)\end{array}$ & $\begin{array}{l}-0.001 \\
(0.004)\end{array}$ & $\begin{array}{l}-0.001 \\
(0.004)\end{array}$ \\
\hline GROWTH & $\begin{array}{c}0.308 * * * \\
(0.032)\end{array}$ & $\begin{array}{c}0.326 * * * \\
(0.034)\end{array}$ & $\begin{array}{c}0.325 * * * \\
(0.032)\end{array}$ & $\begin{array}{c}0.326^{* * * *} \\
(0.031)\end{array}$ & $\begin{array}{c}0.305^{* * *} \\
(0.031)\end{array}$ & $\begin{array}{c}0.303^{* * *} \\
(0.030)\end{array}$ & $\begin{array}{c}0.299 * * * \\
(0.030)\end{array}$ \\
\hline TO & $\begin{array}{c}0.001 \\
(0.003)\end{array}$ & $\begin{array}{l}-0.001 \\
(0.002)\end{array}$ & $\begin{array}{c}0.001 \\
(0.003)\end{array}$ & $\begin{array}{c}0.001 \\
(0.003)\end{array}$ & $\begin{array}{c}0.000 \\
(0.003)\end{array}$ & $\begin{array}{c}0.000 \\
(0.003)\end{array}$ & $\begin{array}{l}-0.000 \\
(0.003)\end{array}$ \\
\hline UN & $\begin{array}{l}-0.060 \\
(0.036)\end{array}$ & $\begin{array}{l}-0.041 \\
(0.035)\end{array}$ & $\begin{array}{l}-0.027 \\
(0.037)\end{array}$ & $\begin{array}{l}-0.019 \\
(0.035)\end{array}$ & $\begin{array}{l}-0.030 \\
(0.034)\end{array}$ & $\begin{array}{l}-0.043 \\
(0.035)\end{array}$ & $\begin{array}{l}-0.044 \\
(0.036)\end{array}$ \\
\hline INF & $\begin{array}{c}0.005 \\
(0.008)\end{array}$ & $\begin{array}{c}0.008 \\
(0.007)\end{array}$ & $\begin{array}{c}0.010 \\
(0.010)\end{array}$ & $\begin{array}{c}0.011 \\
(0.009)\end{array}$ & $\begin{array}{l}-0.001 \\
(0.010)\end{array}$ & $\begin{array}{l}-0.003 \\
(0.011)\end{array}$ & $\begin{array}{l}-0.005 \\
(0.012)\end{array}$ \\
\hline FRI & $\begin{array}{c}0.514 * * * \\
(0.087)\end{array}$ & & & & & & \\
\hline ER & & $\begin{array}{c}1.312 * * * \\
(0.236)\end{array}$ & & & & & \\
\hline DR & & & $\begin{array}{c}1.100 * * * \\
(0.320)\end{array}$ & & & & \\
\hline BBR & & & & $\begin{array}{c}1.193^{* * * *} \\
(0.288)\end{array}$ & & & \\
\hline FC & & & & & $\begin{array}{c}1.001 * * * \\
(0.270)\end{array}$ & & \\
\hline INDFC & & & & & & $\begin{array}{c}0.938 * * * \\
(0.284)\end{array}$ & \\
\hline ACINFFC & & & & & & & $\begin{array}{c}0.781^{* *} \\
(0.309)\end{array}$ \\
\hline Constant & $\begin{array}{c}-1.624 * * \\
(0.591)\end{array}$ & $\begin{array}{c}-1.981 * * * \\
(0.538)\end{array}$ & $\begin{array}{c}-2.670 * * * \\
(0.587)\end{array}$ & $\begin{array}{c}-2.702 * * * \\
(0.552)\end{array}$ & $\begin{array}{c}-1.602 * * * \\
(0.542)\end{array}$ & $\begin{array}{c}-1.460 * * \\
(0.566)\end{array}$ & $\begin{array}{c}-1.343 * * \\
(0.623)\end{array}$ \\
\hline Sargan Test & 72.33 & 62.97 & 88.66 & 78.12 & 74.19 & 75.40 & 77.37 \\
\hline $\operatorname{ar}(2)$ & 0.301 & 0.199 & 0.213 & 0.215 & 0.227 & 0.234 & 0.226 \\
\hline Observations & 612 & 612 & 612 & 612 & 612 & 612 & 612 \\
\hline Number of id & 28 & 28 & 28 & 28 & 28 & 28 & 28 \\
\hline
\end{tabular}

Note. The table reports the estimates of the coefficients and their standard deviation for the period from 1996 to 2018 . The basic equation of the other columns (from 2 to 8 ) can be found in the Data and Methodology section. ****** Denote significance level of 10\%, 5\% and 1\%, respectively. 
Table 7. Fixed effects panel data estimations for 28 European countries from 1996 to 2018 (annual data)

\begin{tabular}{|c|c|c|c|c|}
\hline Variables & Model (1) & (2) & (3) & (4) \\
\hline \multirow[t]{2}{*}{ L.PB } & $0.604 * * *$ & $0.604 * * *$ & $0.613 * * *$ & $0.604 * * *$ \\
\hline & $(0.034)$ & $(0.034)$ & $(0.033)$ & $(0.036)$ \\
\hline \multirow[t]{2}{*}{ DEBT } & 0.010 & 0.010 & $0.018^{* * *}$ & 0.010 \\
\hline & $(0.007)$ & $(0.007)$ & $(0.006)$ & $(0.007)$ \\
\hline \multirow[t]{2}{*}{ GROWTH } & $0.306^{* * *}$ & $0.306 * * *$ & $0.311 * * *$ & $0.297 * * *$ \\
\hline & $(0.028)$ & $(0.028)$ & $(0.028)$ & $(0.028)$ \\
\hline \multirow[t]{2}{*}{ TO } & 0.006 & 0.006 & 0.006 & 0.007 \\
\hline & $(0.005)$ & $(0.005)$ & $(0.005)$ & $(0.006)$ \\
\hline \multirow[t]{2}{*}{ UN } & -0.033 & -0.033 & -0.030 & -0.042 \\
\hline & $(0.055)$ & $(0.055)$ & $(0.054)$ & $(0.052)$ \\
\hline \multirow[t]{2}{*}{ INF } & $0.019^{* * *}$ & $0.019^{* * *}$ & $0.022 * * *$ & $0.018^{* * *}$ \\
\hline & $(0.006)$ & $(0.006)$ & $(0.007)$ & $(0.007)$ \\
\hline \multirow[t]{2}{*}{ ERBBR } & $0.665^{* *}$ & & & \\
\hline & $(0.271)$ & & & \\
\hline \multirow[t]{2}{*}{ ERDR } & & $0.665^{* *}$ & & \\
\hline & & $(0.271)$ & & \\
\hline \multirow[t]{2}{*}{ DRBBR } & & & $0.705^{* *}$ & \\
\hline & & & $(0.294)$ & \\
\hline \multirow[t]{2}{*}{ ACINFFCINDFC } & & & & $0.748^{*}$ \\
\hline & & & & $(0.425)$ \\
\hline \multirow[t]{2}{*}{ Constant } & $-3.122 * * *$ & $-3.122 * * *$ & $-3.822 * * *$ & $-2.955 * *$ \\
\hline & $(0.888)$ & $(0.888)$ & $(0.786)$ & (1.089) \\
\hline Observations & 612 & 612 & 612 & 612 \\
\hline R-squared & 0.565 & 0.565 & 0.564 & 0.565 \\
\hline Number of id & 28 & 28 & 28 & 28 \\
\hline
\end{tabular}

Note. The table reports the estimates of the coefficients and their standard deviation for the period from 1996 to 2018. The basic equation of the other columns (from 2 to 8 ) can be found in the Data and Methodology section. ****** Denote significance level of 10\%, 5\% and 1\%, respectively.

Table 8. Arellano-Bover/ Blundell-Bond dynamic panel data estimations for 28 European countries from 1996 to 2018 (annual data)

\begin{tabular}{|c|c|c|c|c|}
\hline Variables & Model (1) & (2) & (3) & (4) \\
\hline L.PB & $\begin{array}{c}0.595 * * * \\
(0.035)\end{array}$ & $\begin{array}{c}0.595 * * * \\
(0.035)\end{array}$ & $\begin{array}{c}0.637 * * * \\
(0.033)\end{array}$ & $\begin{array}{c}0.639 * * * \\
(0.032)\end{array}$ \\
\hline DEBT & $\begin{array}{l}-0.001 \\
(0.004)\end{array}$ & $\begin{array}{l}-0.001 \\
(0.004)\end{array}$ & $\begin{array}{c}0.001 \\
(0.003)\end{array}$ & $\begin{array}{l}-0.000 \\
(0.004)\end{array}$ \\
\hline GROWTH & $\begin{array}{c}0.326 * * * \\
(0.034)\end{array}$ & $\begin{array}{c}0.326 * * * \\
(0.034)\end{array}$ & $\begin{array}{c}0.329 * * * \\
(0.030)\end{array}$ & $\begin{array}{c}0.299 * * * \\
(0.030)\end{array}$ \\
\hline TO & $\begin{array}{l}-0.001 \\
(0.002)\end{array}$ & $\begin{array}{l}-0.001 \\
(0.002)\end{array}$ & $\begin{array}{c}0.001 \\
(0.003)\end{array}$ & $\begin{array}{c}0.000 \\
(0.003)\end{array}$ \\
\hline UN & $\begin{array}{l}-0.041 \\
(0.035)\end{array}$ & $\begin{array}{l}-0.041 \\
(0.035)\end{array}$ & $\begin{array}{l}-0.015 \\
(0.037)\end{array}$ & $\begin{array}{l}-0.046 \\
(0.036)\end{array}$ \\
\hline INF & $\begin{array}{l}0.008 \\
(0.007)\end{array}$ & $\begin{array}{c}0.008 \\
(0.007)\end{array}$ & $\begin{array}{c}0.011 \\
(0.008)\end{array}$ & $\begin{array}{l}-0.005 \\
(0.012)\end{array}$ \\
\hline ERBBR & $\begin{array}{c}1.312 * * * \\
(0.236)\end{array}$ & & & \\
\hline ERDR & & $\begin{array}{c}1.312 * * * \\
(0.236)\end{array}$ & & \\
\hline DRBBR & & & $\begin{array}{c}1.170^{* * * *} \\
(0.288)\end{array}$ & \\
\hline ACINFFCINDFC & & & & $\begin{array}{c}0.683 * * \\
(0.321)\end{array}$ \\
\hline Constant & $\begin{array}{c}-1.981 * * * \\
(0.538)\end{array}$ & $\begin{array}{c}-1.981 * * * \\
(0.538)\end{array}$ & $\begin{array}{c}-2.681 * * * \\
(0.564)\end{array}$ & $\begin{array}{c}-1.346^{* * *} \\
(0.628)\end{array}$ \\
\hline Sargan Test & 62.97 & 62.97 & 78.37 & 78.72 \\
\hline $\operatorname{ar}(2)$ & 0.199 & 0.199 & 0.219 & 0.224 \\
\hline Obseravtions & 612 & 612 & 612 & 612 \\
\hline Number of id & 28 & 28 & 28 & 28 \\
\hline
\end{tabular}

Note. The table reports the estimates of the coefficients and their standard deviation for the period from 1996 to 2018. The basic equation of the other columns (from 2 to 8 ) can be found in the Data and Methodology section.

$* * * * *$ Denote significance level of $10 \%, 5 \%$ and $1 \%$, respectively. 


\section{Conclusions}

Persistent evidence of fiscal indiscipline and creation of huge fiscal deficits have prompted a debate on how effective are the measures against such deficits. In an effort to discourage deviations from their desirable policies, policy makers applied fiscal rules, fiscal councils and medium-term budgetary frameworks. In this paper, we focused on evaluating the impact of different features of fiscal frameworks, namely fiscal rules and fiscal councils on fiscal performance. We run panel regressions for $28 \mathrm{EU}$ countries from 1996 to 2018 where the primary balance is the dependent variable.

The first set of empirical results shows one lagged primary balance, growth, fiscal rule index, political stability, government effectiveness, budget balanced rule, expenditure rule, debt rule and fiscal council as significant primary balance determinants for European Countries. The same results are extracted by using the approach of Arellano-Bover/ Blundell-Bond Dynamic Panel Data. It has to be mentioned though that when employing the interactions among different types of fiscal rules as well as between fiscal councils (independent fiscal councils and fiscal councils that have access to information) we find that all the combinations are statistically significant.

The outcome of the empirical analysis has policy implications highlighting the factors that countries should focus on, in order to create fiscal surpluses. However, the empirical results for European countries mostly indicate the importance of fiscal rules and fiscal councils on primary balance. Future empirical analysis should also place emphasis on the qualitative characteristics of the individual countries so as to analyze the importance of fiscal institutions on each country. Finally, it is also of particular significance the examination of fiscal institutions on fiscal performance for different countries groups as well as the impact of fiscal institutions on different dependent variables.

\section{References}

Advisory Commision on Intergovernmental Relations. (1987). Fiscal discipline in the federal system: National reform and the experience of the states. U.S. Government Printing Office, Washington.

Alesina, A., \& Bayoumi, T. (1996). The costs and benefits of fiscal rules: Evidence from U.S. states. NBER Working Paper 5614. National Bureau of Economic Research, Cambridge. https://doi.org/10.3386/w5614.

Alesina, A., Tabellini, G., (1990). A positive theory of fiscal deficits \& government debt. Review of Economic Studies 57, No 3, pp 407-414. https://doi.org/10.2307/2298021

Ayuso-i-Casals, J., Gonzáles Hernandez, D., Moulin, L., \& Turrini, A. (2007). Beyond the SGP: Features and effects of EU national-level fiscal rules. Policy instruments for Sound Fiscal Policies, 204-240. https://doi.org/10.2139/ssrn.2004450

Badinger, H., \& Reuter, W. H. (2017). The case of fiscal rules. Economic Modelling, 60, 334-343. https://doi.org/10.1016/j.econmod.2016.09.028

Beetsma, M. W. R., J., Debrun, X., Fang, X., Kim, Y., Lledo, D. V., Mbaye, S., \& Zhang, X. (2019). Independent fiscal councils: Recent trends and performance. European Journal of Political Economy, 57(C), 53-69. https://doi.org/10.1016/j.ejpoleco.2018.07.004.

Bergman, M., Hutchison, M. M., \& Jensen, S. E. (2016). Promoting sustainable public finances in the European Union: The role of fiscal rules and government efficiency. European Journal of Political Economy, 44, 1-19. https://doi.org/10.1016/j.ejpoleco.2016.04.005

Bohn, H., \& Inman, R. P. (1996). Balanced budget rules and public deficits: Evidence from the U.S. states. NBER Working Paper 5533, National Bureau of Economic Research, Inc. Cambridge. http://doi.org//10.3386/w5533

Caselli, F., \& Reynard, J. (2020). Do fiscal rules cause better fiscal balances? A new instrumental variable strategy. European Journal of Poltical Economy, 63(C). https://doi.org/10.1016/j.ejpoleco.2020.101873

Caselli, G. F., \& Wingender, P. (2018). Bunching at 3 Percent: The Maastricht Fiscal Criterion and Governance Deficits. International Monetary Fund Working Papers 18/182. https://doi.org/10.5089/9781484371732.001

Clingermayer, J. C., \& Wood, B. D. (1995). Disentangling patterns of state debt financing. American Political Science Review, 89(1), 108-120. https://doi.org/10.2307/2083078

Debrun et al. (2013). The Functions and Impact of Fiscal Councils. IMF Working paper. International Monetary Fund. https://doi.org/10.13140/RG.2.1.2733.7447

Debrun, X., \& Kumar, M. S. (2007a). Fiscal rules, fiscal councils and all that: Commitment devices, signaling tools or Fiscal policy smokescreens? In Banca d' Italia (Ed.), Current issues and challenges. Papers 
presented at the Banca d' Italia workshop held in Perugia, 29-31 March 2007, Roma, pp. 479-512. https:/doi.org/10.2139/ssrn.2004371

Debrun, X., \& Kumar, M. S. (2007b). The discipline-enhancing role of fiscal institutions: Theory and empirical evidence. International Monetary Fund, Washington. IMF Working Paper WP/07/171. http://dx.doi.org/10.5089/9781451867350.001

Debrun, X., Gerard, M., \& Harris, J. (2012). Has the Time for Fiscal Councils Come at Last? OECD Conference Centre, 23-24.

Debrun, X., Moulin, L., Turrini, A., Ayuso-i-Casalas, J., \& Kumar, M. S. (2008). Tied to the mast? National fiscal rules in the European Union. Economic Policy, 23(54), 297-362. http://dx.doi.org/10.1111/j.1468-0327.2008.00199.x

Debrun, X., Zhang, X., \& Lledó, V. (2017). The fiscal council dataset: A primer to the 2016 vintage. International Monetary Fund.

Eichengreen, B., \& Bayoumi, T. (1994). The political economy of fiscal restrictions: Implications for Europe from the United States. European Economic Review, 38(3-4), 783-791. https://doi.org/10.1016/0014-2921(94)90114-7

Ganelli, G., \& Tervala, J. (2016). The welfare Multiplier of public infrastructure investment No.16/40, International Monetary Fund. http://dx.doi.org/10.5089/9781475516678.001

Grembi, V., Tommaso, N., \& Ugo, T. (2016). Do fiscal rules matter? American Economic Journal: Applied Economics, 8(3), 1-30. https://doi.org/10.1257/app.20150076

Guerguil, M., Mandon, P., \& Tapsoba, R. (2017). Flexible fiscal rules and countercyclical fiscal policy. Journal of Marcoeconomics, 52, 189-220. https://doi.org/10.1016/j.jmacro.2017.04.007

Hagen, J. (2006). Fiscal rules and fiscal performance in the European Union and Japan. Monetary and Economic Studies, 24(1), 25-60.

International Monetary Fund. (2009). Fiscal Rules - Anchoring Expectations for Sustainable Public Finances. December. https://doi.org/10.5089/9781462349531.004

International Monetary Fund. (2012). Fiscal performance, institutional design and decentralisation in European $\begin{array}{lllll}\text { Union countries. International Monetary } & \text { Fund, }\end{array}$ https://doi.org/10.5089/9781475503340.001

Kennedy, S., Robbins, J., \& Delorme, F. (2001). The Role of Fiscal Rules in Determining Fiscal Performance. Fiscal Rules Conference, p. 237. https://doi.org/10.2139/ssrn.2094473

Kopits, G., \& Symansky, S. (1998). Fiscal Policy Rules. Occasional Paper, No. 162. International Monetary Fund, Washington, DC. https://doi.org/10.5089/9781557757043.084

Larch, M., \& Turrini, A. (2010). The cyclically adjusted budget balance in EU fiscal policy making. Intereconomics, 45, 48-60. https://doi.org/10.1007/s10272-010-0324-9

Milesi-Feretti, G. M., \& Moriyama, K. (2004). Fiscal Adjustment in EU Countries: A Balance Sheet Approach. IMF Working Paper, 04/143. https://doi.org/10.2139/ssrn.2040730

Nice, D. C. (1991). The impact of state policies to limit debt financing. Publius, 21(1), 69-82. https://doi.org/10.1093/oxfordjournals.pubjof.a037927

Perotti, R., \& Yianos, K. (2002). Fragmented Fiscal Policy. Journal of Public Economics, 86(2), 191-222. https://doi.org/10.1016/S0047-2727(01)00146-3

Summers, L. H. (2014). Reflections of the new secular stagnation hypothesis. Secular Stagnation, Facts Causes Cures, 27-38. 


\section{Appendix}

Table A1. Definition and source of variables

\begin{tabular}{|c|c|c|}
\hline Variables & Source & Time Period \\
\hline $\begin{array}{l}\text { Government net borrowing or net lending excluding interest payments on consolidated } \\
\text { government liabilities as a percentage of GDP. (PB) }\end{array}$ & EUROSTAT & 1996-2018 \\
\hline $\begin{array}{l}\text { Government debt is defined as total gross debt at nominal value outstanding at the end of } \\
\text { the year and consolidated between and within the sectors of general government. } \\
\text { (DEBT) }\end{array}$ & EUROSTAT & 1996-2018 \\
\hline $\begin{array}{l}\text { Annual percentage growth rate of GDP at market prices based on constant local currency. } \\
\text { Aggregates are based on constant } 2010 \text { U.S. dollars. GDP is the sum of gross value } \\
\text { added by all resident producers in the economy plus any product taxes and minus any } \\
\text { subsidies not included in the value of the products. It is calculated without making } \\
\text { deductions for depreciation of fabricated assets or for depletion and degradation of } \\
\text { natural resources. (GROWTH) }\end{array}$ & WDI & 1996-2018 \\
\hline Sum of exports and imports of goods and services as a percentage of GDP. (TO) & WDI & 1996-2018 \\
\hline $\begin{array}{l}\text { Unemployment refers to the share of the labor force that is without work but available } \\
\text { for and seeking employment. Definitions of labor force and unemployment differ by } \\
\text { country. (UN) }\end{array}$ & EUROSTAT & 1996-2018 \\
\hline Annual percentage of change of consumer price index. (INF) & UNCTAD & 1996-2018 \\
\hline $\begin{array}{l}\text { Dummy for European Monetary Union (value } 1 \text { if each country has the euro as a } \\
\text { currency and } 0 \text { otherwise). (EMU) }\end{array}$ & $\begin{array}{l}\text { EUROPEAN CENTRAL } \\
\text { BANK }\end{array}$ & 1996-2018 \\
\hline $\begin{array}{l}\text { Voice and Accountability indicator ranges from }-2.5 \text { to } 2.5 \text {. For more information about } \\
\text { the definition of Voice and Accountability see Worldwide Governance Indicators. (VAC) }\end{array}$ & WGI & 1996-2018 \\
\hline $\begin{array}{l}\text { Political Stability and Absence of Violence/Terrorism indicator ranges from }-2.5 \text { to } 2.5 \text {. } \\
\text { For more information of Political Stability and Absence of Violence/Terrorism about the } \\
\text { definition see Worldwide Governance Indicators. (PS) }\end{array}$ & WGI & 1996-2018 \\
\hline $\begin{array}{l}\text { Government Effectiveness indicator ranges from }-2.5 \text { to } 2.5 \text {. For more information about } \\
\text { the definition of Government Effectiveness see Worldwide Governance Indicators. (GE) }\end{array}$ & WGI & 1996-2018 \\
\hline $\begin{array}{l}\text { Regulatory Quality ranges from }-2.5 \text { to } 2.5 \text {. For more information about the definition of } \\
\text { Regulatory Quality see Worldwide Governance Indicators. (RQ) }\end{array}$ & WGI & 1996-2018 \\
\hline $\begin{array}{l}\text { Rule of Law indicator ranges from }-2.5 \text { to } 2.5 \text {. For more information about the definition } \\
\text { of Rule of Law see Worldwide Governance Indicators. (ROL) }\end{array}$ & WGI & 1996-2018 \\
\hline $\begin{array}{l}\text { Control of Corruption indicator ranges from }-2.5 \text { to } 2.5 \text {. For more information about the } \\
\text { definition of Control of Corruption see Worldwide Governance Indicators. (COC) }\end{array}$ & WGI & 1996-2018 \\
\hline Fiscal Rule Index. (FRI) & $\begin{array}{c}\text { EUROPEAN } \\
\text { COMMISSION DATASET }\end{array}$ & 1996-2018 \\
\hline $\begin{array}{l}\text { Dummy for expenditure rule (value } 1 \text { if there is an expenditure rule and } 0 \text { otherwise). } \\
\text { (ER) }\end{array}$ & IMF DATASET & 1996-2018 \\
\hline $\begin{array}{l}\text { Dummy for budget balance rule (value } 1 \text { if there is a budget balance rule and } 0 \\
\text { otherwise). (BBR) }\end{array}$ & IMF DATASET & 1996-2018 \\
\hline Dummy for debt rule (value 1 if there is an expenditure rule and 0 otherwise). (DR) & IMF DATASET & 1996-2018 \\
\hline Dummy for fiscal council (value 1 if there is a fiscal council and 0 otherwise). (FC) & IMF DATASET & 1996-2018 \\
\hline $\begin{array}{l}\text { Dummy for Independent fiscal council (value } 1 \text { if there is an independent fiscal council } \\
\text { and } 0 \text { otherwise). (INDFC) }\end{array}$ & IMF DATASET & 1996-2018 \\
\hline $\begin{array}{l}\text { Dummy for fiscal council which has access to information (value } 1 \text { if there is a fiscal } \\
\text { council which has access to information and } 0 \text { otherwise). (ACINFFC) }\end{array}$ & IMF DATASET & 1996-2018 \\
\hline
\end{tabular}

\section{Copyrights}

Copyright for this article is retained by the author(s), with first publication rights granted to the journal.

This is an open-access article distributed under the terms and conditions of the Creative Commons Attribution license (http://creativecommons.org/licenses/by/4.0/). 